\title{
Relationship and Communication: Domain Editors
}

\author{
Mark Krueger, $P h D$
}

Mark Krueger, $\mathrm{PhD}$ is professor and founder of the Youth Work Learning Center, University of Wisconsin-Milwaukee where he teaches and studies youth work. Prior to coming to the university several years ago, he was a child and youth care worker. He has written several articles and books about the field, and consulted and spoken at numerous conferences and agencies in the U.S., Canada, and Europe. His work is focused on understanding youth work as a process of human interaction. Throughout his career he has been an active participant in the effort to develop a profession of child and youth care.

\section{Thom Garfat, $P h D$}

Thom Garfat, PhD has been working in our field for 40 years. He is the cofounder of the International Child and Youth Care Network (www.cyc-net.org), the senior editor of Relational Child \& Youth Care Practice and the developer of the training program "The Therapeutic Use of Daily Life Events". More information about Thom can be found on his company website www.cyc-net.org/transformaction.

\section{Claire King, $E d D$}

Claire King, EdD is a youth advocate and educator who has spent her career as a youth worker in the classroom. Her experiences with young people in formal and informal education in under-resourced schools and youth groups in urban and rural settings in five states led to her interest in positive youth development and appreciative inquiry of the environments and approaches that best facilitate youth voice, identity and vocational awareness. A 2003 Journey Fellow, Claire developed a comprehensive online curriculum for professional youth workers based on the CYC-P competencies. Preceded by 19 years in K-12 schools, Claire recently completed 13 years in higher education in Indiana working in leadership development and transformative educational practice with "failing" schools. She is now an administrator in a small urban New Jersey high school working directly with adolescents and the adults who support their growth. 